\title{
Role of Airway Epithelium-Origin Chemokines and their Receptors in COPD
}

\author{
Hong Chen, Diane Wang and Xiangdong Wang* \\ Department of Pulmonary Medicine, Center for Biomedical Research, Zhongshan Hospital, Fudan University, PR, \\ China
}

\begin{abstract}
Chronic obstructive pulmonary disease (COPD) is characterized with the chronic airway inflammation associated with progressive obstruction of airflow. Airway epithelial cells play an essential role of development in COPD. Chemokines as extracellular signaling proteins have been suggested to be involved in the inflammatory process of COPD. The present review summarized the variation of chemokines in the airway epithelium of COPD patients and discussed the potential roles of chemokines in the pathogenesis of COPD. Increased level of IL-8 was considered as a key and unique chemokine in the initiation and progress of COPD. Others like CXCR3 chemokines and eosinophils-related chemokines should be also considered. Further research will be necessary to explore whether targeting on these chemokines, particularly IL-8 and CXCRs, can be benefit to patients with COPD. It is also important to identify and validate a critical and specific chemokine with differential diagnostic value. The correlation of chemokines with disease severity, diagnosis and therapy in COPD should be further clarified. High-throughout technologies, e.g. genomics, proteomics and bioinformatics, can be more attractive approaches to validate the importance of chemokines in the disease. Although the exact role of chemokines in the pathogenesis of COPD still needs to be explored, anti-chemokines or receptor antagonists may be an alterative of new therapies for patients with COPD.
\end{abstract}

Keywards: COPD, epithelial cells, chemokines, BALF, sputum.

\section{INTRODUCTION}

Chronic obstructive pulmonary disease (COPD) is a chronic lung disease characterized by a progressive airflow limitation and associated with an abnormal inflammatory response of the lungs to noxious particles or gases [1,2]. COPD ranks among the top five leading causes of death worldwide and becomes the top three in the mortality by 2020 [3]. Increasing interests in the clinical features and pathogenesis of COPD reflect the worldwide importance of the disease. The over-production of chemokines and activation of chemokines receptors have been suggested to be involved in the abnormalities seen in COPD. These small attractant proteins occur in different stages of the disease and also in several diseases associated with COPD (Fig. 1). Although the potential roles of inflammatory mediators have been well described in asthma [4, 5], little information is known about the production and role of those mediators in COPD.

Bronchoalveolar lavage (BAL) is the most common manner to sample the components of the epithelial lining fluid and determine the protein composition of the pulmonary airways. The recovered BAL fluid (BALF) contains both lung cells and epithelial lining fluid solutes including proteins and inflammatory mediators [6]. Epithelial cells in the human airway are responsible for multiple functions, e.g. absorption, transport, secretion and defense, and can be

*Address correspondence to this author at the Department of Pulmonary Medicine, Center for Biomedical Research, Zhongshan Hospital, Fudan University, PR, China; Tel: +86 21 64041990x5420; Fax: +86 21 54961729; E-mail: xiangdong.wang@telia.com activated to produce a number of inflammatory mediators to communicate with other cells and initiate the local inflammatory response. Induced sputum has been suggested as a noninvasive method to study airway secretions, cells and biomarkers, e.g. chemokines [7]. The primary human bronchial epithelial cells (PBECs) via biopsies can also provide more precise information about those chemokines. In the present review, we summarize alterations of chemokines recently observed in human airway by different methods, present the potential role of chemokines in the mechanisms and compare the patterns of altered chemokines in COPD with other human airway inflammatory diseases.

\section{CHEMOKINES AND CORRESPONDING RECEP- TORS}

Chemokines are chemotactic cytokines of 8-10 kDa involved in attracting leukocytes into tissues. Since the first chemokine, interleukin (IL)-8, was described [8, 9], over 50 other chemokines have been recognized to interact with $\geqq 17$ different receptors [10]. Based on structural homology around four cysteine residues, the chemokine family can be subdivided into four subclasses, -C-, -CC-, -CXC- and CXXXC-, in which X substitutes for any amino acid. Two subclasses account for most of the chemokines: CXC ( $\alpha$ chemokines) and $\mathrm{CC}$ ( $\beta$-chemokines) chemokines. The $\mathrm{CC}$ chemokines are involved in chemoattraction of eosinophil, monocytes and T-lymphocytes.

Of the CXC chemokines, IL-8, growth related oncogene$\alpha(\mathrm{GRO}-\alpha)$ and epithelial-derived neutrophil activator (ENA78) are of particular interest with their chemoattractant and activating effects on neutrophils. They act through a transmembrane domain-containing seven G-protein-coupled re- 


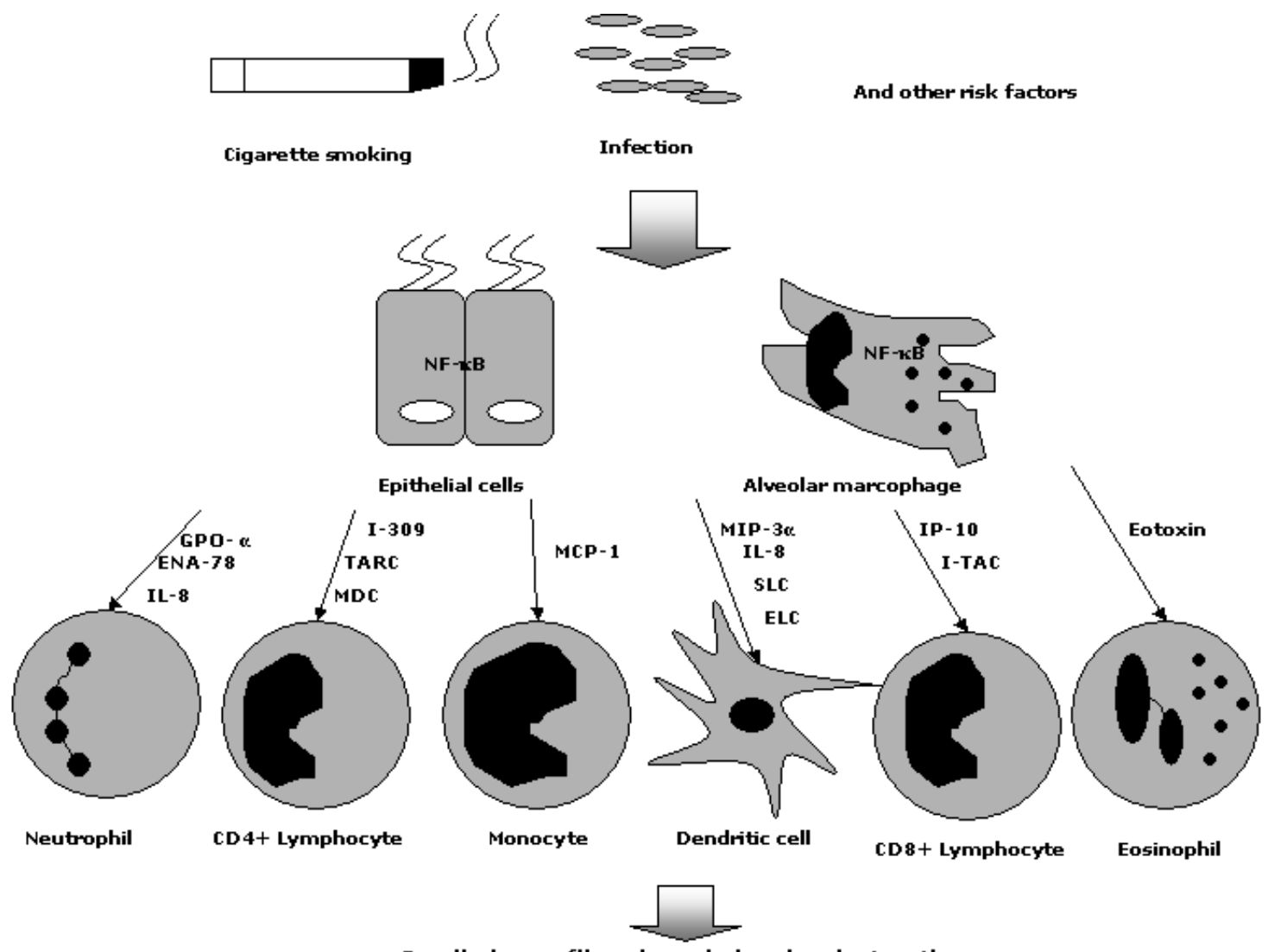

Small airway fibrosis and alveolar destruction

Fig. (1). Schematic illustration of potential mechanism in COPD. Cigarette smoking, infections and other risk factors stimulate airway epithelial cells and alveolar macrophages, leading to activation of the transcription factor nuclear factor (NF- $\kappa \mathrm{B})$. Then these cells could release various chemokines which can recruit different inflammatory cells by binding corresponding receptors. Chemokine-dominant inflammation may result in the development of small airway fibrosis and alveolar destruction.

ceptor, type 2 CXC receptor (CXCR) 2, whereas IL-8 activates CXCR1. Of the larger family of CC chemokines, normal T-cell expressed and secreted (RANTES), macrophage inflammatory protein $1 \alpha(\mathrm{MIP}-1 \alpha)$, monocyte chemotactic protein (MCP) 1, 3 and 4, and eotaxin may also play the important role in development of the disease. Eotaxin acting through the type $3 \mathrm{CC}$ receptor (CCR3) is a selective chemoattractant for eosinophils, whereas RANTES exhibits a range of effects on memory $\mathrm{T}$ cell, basophils and eosinophils, acting through CCR1, 3 and 5. MCP-3 and 4 may recruit eosinophils and mononuclear cells, whereas MCP-1 can recruit monocytes, lymphocytes and basophils and activate mast cells and basophils. Those ligands and their receptors on airway epithelia obtained from BALF, sputum or biopsies from patients with COPD are listed in Table 1. Of those, IL8 has been considered to play the critical role in COPD. Although CC chemokines are of great relevance to asthma, the elevation of some chemokines can be also found in COPD.

\section{CXCL8/IL-8 AND ITS RECEPTORS (CXCR1 AND CXCR2)}

Increased neutrophils are a feature of airway inflammation in patients with COPD, particularly patients with more severe disease, during exacerbations and with cigarette smoking. CXCL8/IL-8 is the most significant chemokine for neutrophils, which is produced from endothelial and epithelial cells in the airway. IL-8 acts via CXCR1 and 2. CXCR2 protein, but not CXCR1, was expressed by bronchial epithelial cells in COPD patients, mainly in the injured areas [11]. Various inflammatory responses that are of potential relevance in COPD pathophysiology did not affect the transcription regulation and surface expression of CXCR1 and CXCR2 on PBECs [12]. CXCR1 and CXCR2 were found to be significantly upregulated at exacerbations of COPD [13] and proposed to play important roles in mediating IL8induced chemotaxis of neutrophils $[14,15]$ and be the target for therapeutic strategies.

The expression of IL-8 protein and mRNA significantly increased in bronchiolar epithelial cells of patients with COPD, in response to several stimuli, including TNF- $\beta$, endothelin-1 (ET-1), bacterial products, lipopolysaccharide (LPS), RV infection, TNF- $\alpha$, oxidative stress and cigarette smoke [16-20]. The secretion of IL- 8 was suggested to be regulated transcrioptionally by several transcription factors, among which NF- $\mathrm{BB}$ is predominant [21]. Via CXCRs, IL-8 could activate protein kinase B (Akt) and GTPases, leading to enhanced neutrophil adherence to endothelial cells by increasing expression of $\beta_{2}$-integrins and directing cell migration. Protein kinase B activates phosphoinositide 3 kinase, which then induces F-actin polymerization, resulting in 
Table 1. Chemokines Detected in Patients with COPD and other Associated Diseases in Different Samples

\begin{tabular}{|c|c|c|c|c|c|c|c|}
\hline Chemokines & $\begin{array}{c}\text { Common } \\
\text { Name }\end{array}$ & $\begin{array}{c}\text { Corresponding } \\
\text { Receptors }\end{array}$ & $\begin{array}{l}\text { Target } \\
\text { Cells }\end{array}$ & Stage & Sputum & BALF & PBECs \\
\hline CXCL1 & GPO- $\alpha$ & CXCR2 & $\mathrm{N}$ & COPD & $(62) \uparrow$ & & $(20) \uparrow$ \\
\hline \multirow[t]{5}{*}{ CXCL8 } & \multirow[t]{5}{*}{ IL-8 } & \multirow[t]{5}{*}{ CXCR2,1 } & \multirow[t]{5}{*}{ DC,N, Ep } & ECOPD & $\begin{array}{c}(7,29,34,35, \\
37) \uparrow\end{array}$ & $(22,34) \uparrow$ & \\
\hline & & & & COPD & $\begin{array}{c}(31,44,50,71) \\
\uparrow\end{array}$ & $(52,65) \uparrow$ & $(20,21,30,79) \uparrow$ \\
\hline & & & & AATD & $(42) \uparrow$ & & \\
\hline & & & & BHR & $(43) \uparrow$ & & \\
\hline & & & & CS & & $(38,52) \uparrow$ & \\
\hline CXCL9 & Mig & CXCR3 & Ep & COPD & & $(52) \uparrow$ & \\
\hline \multirow[t]{2}{*}{ CXCL11 } & \multirow[t]{2}{*}{ I-TAC } & \multirow[t]{2}{*}{ CXCR3 } & \multirow[t]{2}{*}{ Th1 } & COPD & & $(52) \uparrow$ & \\
\hline & & & & $\mathrm{CS}$ & & $(52) \uparrow$ & \\
\hline \multirow[t]{3}{*}{ CCL2 } & \multirow[t]{3}{*}{ MCP-1 } & \multirow[t]{3}{*}{$\mathrm{CCR} 2$} & \multirow[t]{3}{*}{ M } & COPD & $(62) \uparrow$ & $(52,65) \uparrow$ & $(79) \uparrow$ \\
\hline & & & & $\mathrm{CB}$ & & $(67) \uparrow$ & \\
\hline & & & & $\mathrm{CS}$ & & $(52) \uparrow$ & \\
\hline \multirow[t]{2}{*}{ CCL3 } & \multirow[t]{2}{*}{ MIP- $1 \alpha$} & \multirow[t]{2}{*}{ CCR5 } & \multirow[t]{2}{*}{$\mathrm{E}$} & COPD & & $(63) \uparrow$ & $(79) \uparrow$ \\
\hline & & & & $\mathrm{CB}$ & $(64) \uparrow$ & (67)x & \\
\hline CCL17 & TARC & CCR4,CCR8 & Th2 & COPD & & $(53) \uparrow$ & \\
\hline CCL20 & MIP-3 $\alpha$ & CCR6 & $\mathrm{DC}, \mathrm{N}, \mathrm{T}$ & COPD & $(80) \uparrow$ & & \\
\hline CCL22 & MDC & $\mathrm{CCR} 4$ & Th2 & COPD & & $(53) \uparrow$ & \\
\hline
\end{tabular}

Abbreviations in Table 1.: Mac, macrophage. En, endothelial cell. DC, dentric cell. N, neutrophil. T, T lymphocyte. Ep, epithelial cell. ECOPD, exacerbation of COPD. CB, chronic brochintis. AATD, alpha-1-antitrypsin deficiency. BHR, asymptomatic, nonspecific airway hyperresponsiveness .CS, cigarette smoking. $\uparrow$, up-regulation. X, undetectable. Sputum, induced sputum samples. BALF, bronchial alveolar lavage fluid. PBECs, primary bronchoepithelial cells obtained from human.

pseudopod formation and chemotaxis [22]. While activating Ras and mitogen-activated protein kinases (MAPK) pathway, IL-8 could also lead to the degranulation in neutrophils. MAPK pathway was suggested to mediate the effect of nicotine through ERK 1/2 and JNK rather than p38 in human bronchial epithelial cells treated with nicotine [23]. These effects could be down-regulated by the intracellular regulator of $\mathrm{G}$-protein signaling proteins by reducing the half-life of the active GTP-bound state of CXCR, leading to reduced IL8-induced neutrophil migration and adherence [24]. Mucins glycoproteins were overproduced and hypersecreted in COPD, predominantly including MUC5AC and MUC5B in human airway. IL-8 was shown to increase MUC5AC abun- dance at the posttranscriptional level in lung epithelial cells and normal human bronchial epithelial cells [25], as shown in Fig. (3).

The concentration of IL- 8 in the sputum and BALF from patients with COPD was found significantly higher than those with asthma [26-28]. The level of IL-8 varied among different stages of COPD [29]. PBECs and sputum cells from patients with stable COPD show significantly higher release of IL- 8 induced by TNF- $\alpha$, as compared to smokers and healthy controls $[20,21,30]$.The concentration of IL-8 in sputum was closely associated with the degree of airflow obstruction and suggested as a biomarker to evaluate the severity of airway inflammation [31]. Clinically stable, 


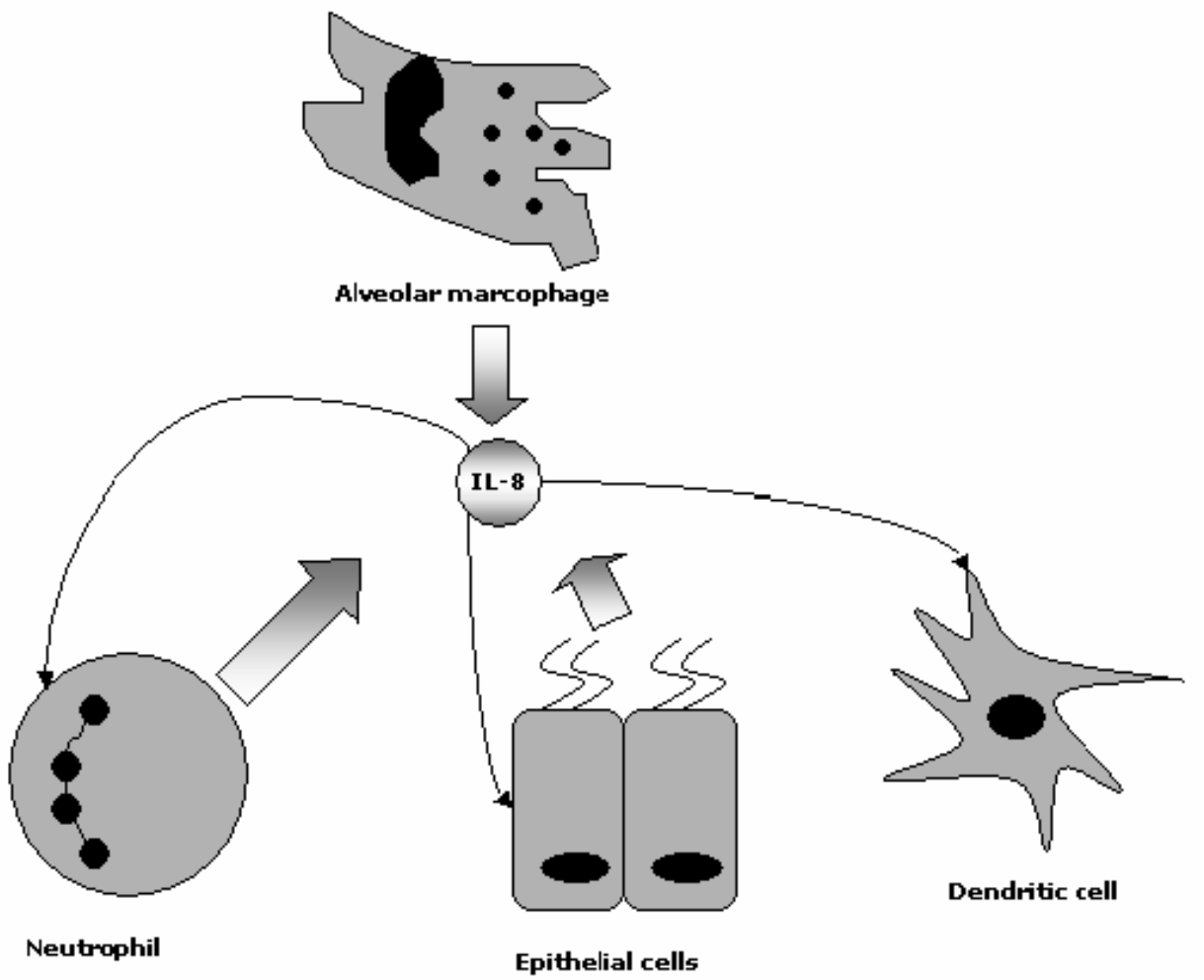

Fig. (2). The role of IL-8 in the inflammation of COPD. IL-8 can be produced by the airway epithelial cells, in addition to neutrophils and macrophages, and then interacts with CXCR1 and CXCR2 on neutrophils, epithelial cells and dendritic cells, leading to different responses.

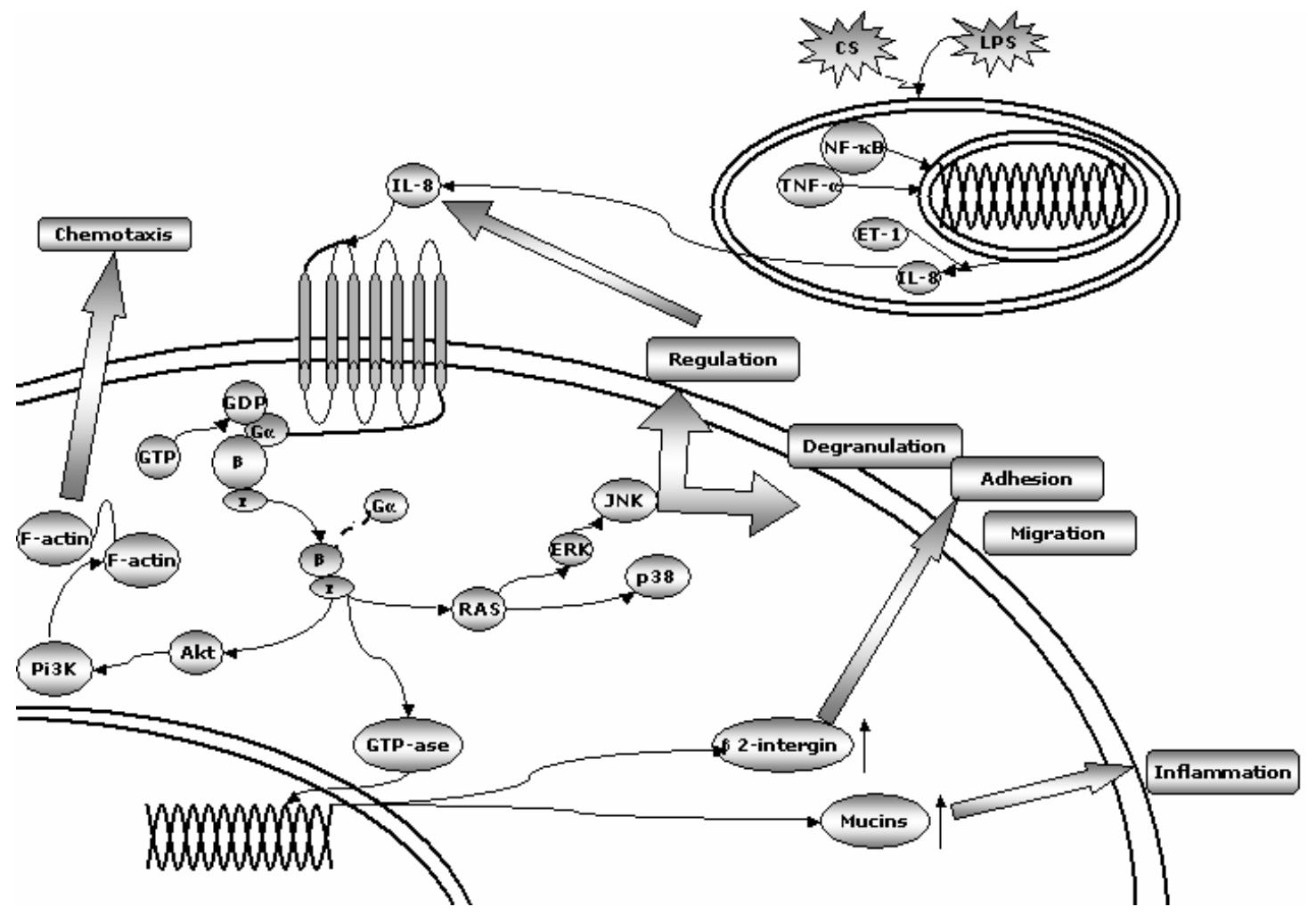

Fig. (3). The regulation of IL-8 in COPD. In response to stimulus, IL- 8 could be upregulated in epithelial cells where NF- $\kappa B$, INF- $\alpha$ and ET-1 may influence the production of IL-8. IL-8 leads to activation of complex signaling pathways and initiates the airway inflammation via CXCRs. 
moderate COPD was also found to be associated with equally stable IL-8 in sputum [32]. Patients with more frequent exacerbations had the higher baseline of IL-8 in sputum, probably predicting the frequency of exacerbation occurrence [33]. IL-8 levels in BALF from patients with stable COPD had no further increase if exacerbations did not occur [34]. However, IL-8 levels in the sputum and in PBECs increased during exacerbations [13, 34, 35]. Infections are a major trigger of exacerbations of COPD. The sputum levels of IL-8 increased in both viral and bacterial infections along with the detection of pathogen [36, 37].

Cigarette smoking, as a major cause of COPD, was found to be associated with increasing amounts of airway IL-8 [38]. The sputum levels of IL-8 significantly elevated in healthy smokers versus COPD patients with smoking history [39], suggesting ongoing inflammation in airways and circulation of patients with COPD after smoking cessation. The a1-antiprotease deficiency was found to be associated with COPD [40], while higher level of IL-8 was detected in a1antiprotease deficiency patients with or without airflow obstruction [41, 42], similar to stable COPD, supporting the hypothesis of a genetic risk factor for COPD. Likely in asymptomatic, nonspecific airway hyperresponsiveness, the sputum level of IL-8 also increased as compared with control subjects [43], predisposing to development of COPD.

The assessment of airway inflammation and bronchodilator responses could help the selection of specific therapies and the prediction of clinical outcomes for COPD patients [44]. Clinical study demonstrated that long-term treatment with theophylline could reduce airway inflammation in stable COPD patients by decreasing IL-8 level [45]. The production of IL- 8 could be reduced by inhaled steroids in both BALF and PBECs [46, 47]. Other antagonists, e.g. theophylline [45], clarithromycin [48], monoclonal antibody against IL-8 $[49,50]$, could also down-regulate the expression of IL8 and inhibit neutrophil chemotaxis.

\section{CXCR3 CHEMOKINES}

CXCR3 is preferentially expressed on lymphocytes, particularly on type-1 T-lymphocytes. It could also be detected in the $S+G(2) / M$ phases in the cell cycle of human airway epithelial cells [51]. CXCR3 interacts with interferon- $\gamma-$ inducible protein of $10 \mathrm{kDa}$ (IP-10; CXCL10) and interferon-inducible T cell- $\alpha$ chemoattractant (I-TAC; CXCL11). All three chemokines produced by stimulated bronchial epithelium could be upregulated and found in BALF of COPD patients $[52,53]$, while CXCL11 might be also regulated by other factors [54]. Upon stimulus, CXCR3 was triggered to express in human airway epithelial cells [55], playing a central role in the trafficking of $\mathrm{T}$ lymphocytes from the pulmonary interstitial tissue into both large and peripheral airways during the onset and resolution of pulmonary inflammation $[52,56,57]$. These results may be valuable in designing novel strategies to antagonize CXCR3 mediated immunological reactions and chemotactic effects on $\mathrm{T}$ cells.

CD8(+) $\mathrm{T}$ lymphocytes release IFN- $\gamma$ which stimulates airway epithelial cells to produce CXCR3 chemokines, leading to the secondary recruitment of CD8(+) T lymphocytes. The number of CXCR3 (+) cells in the epithelium and submucosa was found to increase in smokers who developed COPD [56]. These patients had a chronic airway inflamma- tion characterized by an increased infiltration of $\mathrm{T}$ lymphocytes, particularly CD8(+), in the airways and lung parenchyma. Activation of CXCR3 could induce DNA synthesis, cell proliferation and stimulation of MAPK pathways [51]. CXCL11 could stimulate the migration of T lymphocytes between the bronchial epithelia in either direction [58]. IkappaB kinase 2 was involved in the IFN- $\gamma$-stimulated release of CXCR3 ligands through a novel mechanism independent $\mathrm{NF}-\kappa \mathrm{B}$ [54]. In human airway epithelial cells, CXCR3-mediated chemotaxis was involved by a $\mathrm{G}$ protein, which activates both the p38 MAPK and PI3K pathways in a calcium-independent fashion [58].

\section{CXCR2 AND CXCL1}

GRO- $\alpha /$ CXCL1 was secreted by alveolar macrophages and airway epithelial cells in response to stimulation of TNF- $\alpha$ and IL-17 in COPD [20, 21, 59, 60]. It could activate neutrophils, monocytes, basophils and $\mathrm{T}$ lymphocytes via CXCR2 [61]. PBECs from patients with COPD showed significantly higher in TNF- $\alpha$-induced release of GRO- $\alpha$ compared to those from smokers without airflow limitation [20]. In sputum, the levels of GRO- $\alpha$ and MCP-1 had significantly positive correlation with neutrophil numbers, contributing to the inflammatory load associated with COPD [62].

\section{CHEMOKINES AND CORRESPONDING RECEP- TORS}

\section{CCL2, CCL3 and CCL4}

MCP-1/CCL2, MIP-1 $\alpha /$ CCL3 and MIP-1 $\beta / C C L 4$ are $\mathrm{CC}$-chemokines, as chemoattractants for inflammatory cells like macrophages, lymphocytes and eosinophils. Higher level of CCL3 in BALF was found to be positively correlated with numbers of alveolar macrophages from BALF [63]. This may have relations with the exaggeration of inflammatory process in the airway. The levels of MIP-1 $\beta$ in sputum from COPD patients were significantly higher than that from the healthy [64]. Higher sputum levels of MCP-1 might be involved in the differentiation of monocytes into macrophages, a role in the pathogenesis of inflammation in COPD [62, 65]. MCP-1 was released from lung epithelial cells in patients with a1-antiprotease deficiency, perhaps contributing to emphysema [66]. On the contrary, MIP-1 $\beta$ was found to a potential chemoattractant for eosinophils in patients with chronic brochintis [64, 67].

\section{CCR5}

$\mathrm{CD} 8+\mathrm{T}$ cells are considered as the key player in the pathogenesis of COPD. Loss of lung function in patients with COPD was associated with a high percentage of CD4+ and CD8+ $\mathrm{T}$ lymphocytes expressing CCR5 and CXCR3 [52, 68, 69]. However severe COPD is characterized by lower numbers of $\mathrm{CD} 3+$ and $\mathrm{CD} 8+$ cells and CD3+ cells coexpressing CXCR3 and CCR5. T lymphocyte infiltration was inversely correlated with the degree of airflow limitation [70]. These findings are consistent with systemic inflammation in COPD associated with an increased influx of cytotoxic and Th1 cells into the airway.

\section{Eosinophil-Selective Chemokines}

While neutrophils and IL-8 may have a great influence on nonreversible obstructive airways, eosinophilic inflammation may play a substantial role in COPD [44]. Eosinophils 
increased in COPD airways and lungs, although they were not considered as the predominant inflammatory cells as they are in asthma. There was a small increase of eosinophils and eosinophil basic proteins in sputum and BALF from patients with COPD or exacerbations of chronic brochintis [38, 71, 72]. RANTES/CCL5 could activate CCR3 and was strongly expressed in airway epithelial cells in COPD and CB exacerbation [73]. The levels of CCL5 in BALF and sputum of smokers were higher than nonsmokers $[52,74,75]$, suggesting a potential role for CCL5-CCR3 signaling in COPD. Although studies have found an elevated level of CCL11 in BALF [76], the levels of CCL11 in sputum was much higher in asthma than COPD [27]. These investigations reveals that CCL11 may not have prominent function in COPD as it in asthma. It is still questionable that the over-expression of CCR4 exists in asthma and COPD [77].

\section{COMPARISON WITH ASTHMA}

Both asthma and COPD have chronic airway inflammation. Severe asthma shares similar clinical phenomena with COPD. However, the difference in inflammatory cells with different patterns of chemokines may be one of the most important factors between two diseases. Studies demonstrated an increased proportion of eosinophils in asthmatic BALF, whereas more neutrophils were observed in COPD. The production of IL-8 in the airway, e.g. sputum and BALF, in patients with COPD was higher than those in asthmatics [28, 65, 71, 77, 78]. The evaluation of BALF reveals more differences in biochemical features of airways inflammation in two diseases than that of induced sputum [28]. In contrast to IL-8, the expression of several T cells attracting chemokines, such as CXCL10, CCL17 and CCL22, in the epithelium was not significantly different between asthma and COPD, but significantly higher than nonsmokers [53]. This may indicate the potential common pathological mechanisms of asthma and COPD.

\section{SUMMARY AND FUTURE INDICATION}

Many chemokines may contribute to the pathogenesis of chronic inflammation and structural changes in COPD. The airway epithelial cells act the primary player to produce chemokines, in addition to activated inflammatory cells, such as alveolar macrophages, neutrophils and $\mathrm{T}$ lymphocytes. The airway epithelium-produced chemokines in COPD patients may be involved in the pathological injury and dysfunction of the lungs. The recruitment of neutrophils by IL- 8 has been recognized as a key and unique role in the initiation and progress of COPD. Others like CXCR3 chemokines and eosinophils-related chemokines should be also considered. Further research will be necessary to explore whether targeting on these chemokines, particularly IL8 and CXCRs, can be benefit to patients with COPD. It is also important to identify and validate a critical and specific chemokine with differential diagnostic value. The correlation of chemokines with disease severity, diagnosis and therapy in COPD should be further clarified. High-throughout technologies, e.g. genomics, proteomics and bioinformatics, can be more attractive approaches to validate the importance of chemokines in the disease. Although the exact role of chemokines in the pathogenesis of COPD still needs to be explored, anti-chemokines or receptor antagonists may be an alternative of new therapies for patients with COPD.
The review was supported by by grants from the programs of Science and Technology Commission of Shanghai Municipality (08PJ1402900, 08DZ2293104 and 09540702600), Fudan University and Zhongshan Hospital Grant for Distinguished Professor, and Shanghai Leading Academic Discipline Project (T0206, B115).

\section{REFERENCES}

[1] Celli BR, MacNee W. Standards for the diagnosis and treatment of patients with COPD: a summary of the ATS/ERS position paper. Eur Respir J 2004; 23: 932-46.

[2] Pauwels RA, Rabe KF. Burden and clinical features of chronic obstructive pulmonary disease (COPD). Lancet 2004; 364: 613-20.

[3] Lopez AD, Murray CC. The global burden of disease, 1990-2020. Nat Med 1998; 4: 1241-3.

[4] Barnes PJ, Chung KF, Page CP. Inflammatory mediators of asthma: an update. Pharmacol Rev 1998; 50: 515-96.

[5] Chung KF, Barnes PJ. Cytokines in asthma. Thorax 1999; 54: 82557.

[6] Henderson AJ. Bronchoalveolar lavage. Arch Dis Child 1994; 70: 167-9.

[7] Daldegan MB, Teixeira MM, Talvani A. Concentration of CCL11, CXCL8 and TNF-alpha in sputum and plasma of patients undergoing asthma or chronic obstructive pulmonary disease exacerbation. Braz J Med Biol Res 2005; 38: 1359-65.

[8] Walz A, Peveri P, Aschauer H, Baggiolini M. Purification and amino acid sequencing of NAF, a novel neutrophil-activating factor produced by monocytes. Biochem Biophys Res Commun 1987; 149: 755-61.

[9] Yoshimura T, Matsushima K, Oppenheim JJ, Leonard EJ. Neutrophil chemotactic factor produced by lipopolysaccharide (LPS)stimulated human blood mononuclear leukocytes: partial characterization and separation from interleukin 1 (IL 1). J Immunol 1987; 139: 788-93.

[10] Luster AD. Chemokines--chemotactic cytokines that mediate inflammation. N Engl J Med 1998; 338: 436-45.

[11] De Boer WI. Cytokines and therapy in COPD: a promising combination? Chest 2002; 121: 209S-18S.

[12] Farkas L, Hahn MC, Schmoczer M, et al. Expression of CXC chemokine receptors 1 and 2 in human bronchial epithelial cells. Chest 2005; 128: 3724-34.

[13] Qiu Y, Zhu J, Bandi V, et al. Biopsy neutrophilia, neutrophil chemokine and receptor gene expression in severe exacerbations of chronic obstructive pulmonary disease. Am J Respir Crit Care Med 2003; 168: 968-75.

[14] Gonsiorek W, Fan X, Hesk D, Fossetta J, Qiu H, Jakway J, et al. Pharmacological characterization of Sch527123, a potent allosteric CXCR1/CXCR2 antagonist. J Pharmacol Exp Ther 2007; 322: 47785 .

[15] Hammond ME, Lapointe GR, Feucht PH, et al. IL-8 induces neutrophil chemotaxis predominantly via type I IL-8 receptors. J Immunol 1995; 155: 1428-33.

[16] de Boer WI, Sont JK, van Schadewijk A, Stolk J, van Krieken JH, Hiemstra PS. Monocyte chemoattractant protein 1, interleukin 8, and chronic airways inflammation in COPD. J Pathol 2000; 190: 619-26.

[17] Johnston SL, Papi A, Bates PJ, Mastronarde JG, Monick MM, Hunninghake GW. Low grade rhinovirus infection induces a prolonged release of IL-8 in pulmonary epithelium. J Immunol 1998; 160: 6172-81.

[18] Newcomb DC, Sajjan US, Nagarkar DR, Goldsmith AM, Bentley JK, Hershenson MB. Cooperative effects of rhinovirus and TNF\{alpha\} on airway epithelial cell chemokine expression. Am J Physiol Lung Cell Mol Physiol 2007; 293: L1021-8.

[19] Peng H, Chen P, Cai Y, Chen Y, Wu QH, Li Y, et al. Endothelin-1 increases expression of cyclooxygenase-2 and production of interlukin-8 in hunan pulmonary epithelial cells. Peptides 2008; 29: 419-24.

[20] Schulz C, Krätzel K, Wolf K, Schroll S, Köhler M, Pfeifer M. Activation of bronchial epithelial cells in smokers without airway obstruction and patients with COPD. Chest 2004; 125: 1706-13.

[21] Profita M, Chiappara G, Mirabella F, Di Giorgi R, Chimenti L, Costanzo G, et al. Effect of cilomilast (Ariflo) on TNF-alpha, IL-8, and GM-CSF release by airway cells of patients with COPD. Tho$\operatorname{rax} 2003 ; 58: 573-9$. 
[22] Chcialowski A, Plusa T, Lubinski W, Pirozynska E, Stankiewicz W, Carewicz R. [IL-8 and T-lymphocytes expressing adhesion molecules LFA-1 (CD11a/CD18), Mac-1 (CD11b/CD18) Lsel in lower respiratory tract obstructive disease]. Pol Merkur Lekarski 2003; 14: 9-12.

[23] Tsai JR, Chong IW, Chen CC, Lin SR, Sheu CC, Hwang JJ. Mitogen-activated protein kinase pathway was significantly activated in human bronchial epithelial cells by nicotine. DNA Cell Biol 2006; 25: 312-22.

[24] Bowman EP, Campbell JJ, Druey KM, Scheschonka A, Kehrl JH, Butcher EC. Regulation of chemotactic and proadhesive responses to chemoattractant receptors by RGS (regulator of G-protein signaling) family members. J Biol Chem 1998; 273: 28040-8.

[25] Bautista MV, Chen Y, Ivanova VS, Rahimi MK, Watson AM, Rose MC. IL-8 regulates mucin gene expression at the posttranscriptional level in lung epithelial cells. J Immunol 2009; 183: 2159-66.

[26] Beeh KM, Beier J, Kornmann O, Mander A, Buhl R. Long-term repeatability of induced sputum cells and inflammatory markers in stable, moderately severe COPD. Chest 2003; 123: 778-83.

[27] Gorska K, Krenke R, Domagala-Kulawik J, et al. Comparison of cellular and biochemical markers of airway inflammation in patients with mild-to-moderate asthma and chronic obstructive pulmonary disease: an induced sputum and bronchoalveolar lavage fluid study. J Physiol Pharmacol 2008; 59 Suppl 6: 271-83.

[28] Hollander C, Sitkauskiene B, Sakalauskas R, Westin U, Janciauskiene SM. Serum and bronchial lavage fluid concentrations of IL-8, SLPI, sCD14 and sICAM-1 in patients with COPD and asthma. Respir Med 2007; 101: 1947-53.

[29] Hacievliyagil SS, Gunen H, Mutlu LC, Karabulut AB, Temel I. Association between cytokines in induced sputum and severity of chronic obstructive pulmonary disease. Respir Med 2006; 100: 846-54.

[30] Fuke S, Betsuyaku T, Nasuhara Y, Morikawa T, Katoh H, Nishimura M. Chemokines in bronchiolar epithelium in the development of chronic obstructive pulmonary disease. Am J Respir Cell Mol Biol 2004; 31: 405-12.

[31] Yamamoto C, Yoneda T, Yoshikawa M, Fu A, Tokuyama T, Tsukaguchi K, et al. Airway inflammation in COPD assessed by sputum levels of interleukin-8. Chest 1997; 112: 505-10.

[32] Bhowmik A, Seemungal TA, Sapsford RJ, Wedzicha JA. Relation of sputum inflammatory markers to symptoms and lung function changes in COPD exacerbations. Thorax 2000; 55: 114-20.

[33] Chin CL, Manzel LJ, Lehman EE, Humlicek AL, Shi L, Starner $\mathrm{TD}$, et al. Haemophilus influenzae from patients with chronic obstructive pulmonary disease exacerbation induce more inflammation than colonizers. Am J Respir Crit Care Med 2005; 172: 85-91.

[34] Drost EM, Skwarski KM, Sauleda J, Soler N, Roca J, Agusti A, et $a l$. Oxidative stress and airway inflammation in severe exacerbations of COPD. Thorax 2005; 60: 293-300.

[35] Aaron SD, Angel JB, Lunau M, Wright K, Fex C, Le Saux N, et al. Granulocyte inflammatory markers and airway infection during acute exacerbation of chronic obstructive pulmonary disease. Am J Respir Crit Care Med 2001; 163: 349-55.

[36] Vernooy JH, Kucukaycan M, Jacobs JA, Chavannes NH, Buurman WA, Dentener MA, et al. Local and systemic inflammation in patients with chronic obstructive pulmonary disease: soluble tumor necrosis factor receptors are increased in sputum. Am J Respir Crit Care Med 2002; 166: 1218-24.

[37] Wilkinson TM, Hurst JR, Perera WR, Wilks M, Donaldson GC, Wedzicha JA. Effect of interactions between lower airway bacterial and rhinoviral infection in exacerbations of COPD. Chest 2006; 129: 317-24.

[38] Pesci A, Balbi B, Majori M, Cacciani G, Bertacco S, Alciato P, et al. Inflammatory cells and mediators in bronchial lavage of patients with chronic obstructive pulmonary disease. Eur Respir J 1998; 12 : 380-6.

[39] Senior RM, Anthonisen NR. Chronic obstructive pulmonary disease (COPD). Am J Respir Crit Care Med 1998; 157: S139-47.

[40] Gompertz S, Hill AT, Bayley DL, Stockley RA. Effect of expectoration on inflammation in induced sputum in alpha-1-antitrypsin deficiency. Respir Med 2006; 100: 1094-9.

[41] Iiboshi H, Ashitani J, Katoh S, Sano A, Matsumoto N, Mukae H, et $a l$. Long-term treatment with theophylline reduces neutrophils, interleukin- 8 and tumor necrosis factor-alpha in the sputum of pa- tients with chronic obstructive pulmonary disease. Pulm Pharmacol Ther 2007; 20: 46-51.

[42] Malerba M, Ricciardolo F, Radaeli A, Torregiani C, Ceriani L, Mori E, et al. Neutrophilic inflammation and IL-8 levels in induced sputum of alpha-1-antitrypsin PiMZ subjects. Thorax 2006; 61: 129-33.

[43] Betz R, Kohlhaufl M, Kassner G, Mullinger B, Maier K, Brand P, et al. Increased sputum IL-8 and IL-5 in asymptomatic nonspecific airway hyperresponsiveness. Lung 2001; 179: 119-33.

[44] Perng DW, Huang HY, Chen HM, Lee YC, Perng RP. Characteristics of airway inflammation and bronchodilator reversibility in COPD: a potential guide to treatment. Chest 2004; 126: 375-81.

[45] Ozol D, Aysan T, Solak ZA, Mogulkoc N, Veral A, Sebik F. The effect of inhaled corticosteroids on bronchoalveolar lavage cells and IL-8 levels in stable COPD patients. Respir Med 2005; 99: 1494-500.

[46] Basyigit I, Yildiz F, Ozkara SK, Yildirim E, Boyaci H, Ilgazli A. The effect of clarithromycin on inflammatory markers in chronic obstructive pulmonary disease: preliminary data. Ann Pharmacother 2004; 38: 1400-5.

[47] Patel IS, Roberts NJ, Lloyd-Owen SJ, Sapsford RJ, Wedzicha JA. Airway epithelial inflammatory responses and clinical parameters in COPD. Eur Respir J 2003; 22: 94-9.

[48] Mahler DA, Huang S, Tabrizi M, Bell GM. Efficacy and safety of a monoclonal antibody recognizing interleukin-8 in COPD: a pilot study. Chest 2004; 126: 926-34.

[49] Aksoy MO, Yang Y, Ji R, Reddy PJ, Shahabuddin S, Litvin J, et al. CXCR3 surface expression in human airway epithelial cells: cell cycle dependence and effect on cell proliferation. Am J Physiol Lung Cell Mol Physiol 2006; 290: L909-18.

[50] Beeh KM, Kornmann O, Buhl R, Culpitt SV, Giembycz MA, Barnes PJ. Neutrophil chemotactic activity of sputum from patients with COPD: role of interleukin 8 and leukotriene B4. Chest 2003; 123: 1240-7.

[51] Torvinen M, Campwala H, Kilty I. The role of IFN-gamma in regulation of IFN-gamma-inducible protein 10 (IP-10) expression in lung epithelial cell and peripheral blood mononuclear cell cocultures. Respir Res 2007; 8: 80 .

[52] Brozyna S, Ahern J, Hodge G, Nairn J, Holmes M, Reynolds PN, et al. Chemotactic mediators of Th1 T-cell trafficking in smokers and COPD patients. Copd 2009; 6: 4-16.

[53] Ying S, O'Connor B, Ratoff J, Meng Q, Fang C, Cousins D, et al. Expression and cellular provenance of thymic stromal lymphopoietin and chemokines in patients with severe asthma and chronic obstructive pulmonary disease. J Immunol 2008; 181: 2790-8.

[54] Spurrell JC, Wiehler S, Zaheer RS, Sanders SP, Proud D. Human airway epithelial cells produce IP-10 (CXCL10) in vitro and in vivo upon rhinovirus infection. Am J Physiol Lung Cell Mol Physiol 2005; 289: L85-95.

[55] Porter JC, Falzon M, Hall A. Polarized localization of epithelial CXCL11 in chronic obstructive pulmonary disease and mechanisms of T cell egression. J Immunol 2008; 180: 1866-77.

[56] Saetta M, Mariani M, Panina-Bordignon P, Turato G, Buonsanti C, Baraldo $\mathrm{S}$, et al. Increased expression of the chemokine receptor CXCR3 and its ligand CXCL10 in peripheral airways of smokers with chronic obstructive pulmonary disease. Am J Respir Crit Care Med 2002; 165: 1404-9.

[57] Shahabuddin S, Ji R, Wang P, Brailoiu E, Dun N, Yang Y, et al. CXCR3 chemokine receptor-induced chemotaxis in human airway epithelial cells: role of p38 MAPK and PI3K signaling pathways. Am J Physiol Cell Physiol 2006; 291: C34-9.

[58] Jones CE, Chan K. Interleukin-17 stimulates the expression of interleukin-8, growth-related oncogene-alpha, and granulocytecolony-stimulating factor by human airway epithelial cells. Am J Respir Cell Mol Biol 2002; 26: 748-53.

[59] Geiser T, Dewald B, Ehrengruber MU, Clark-Lewis I, Baggiolini M. The interleukin-8-related chemotactic cytokines GRO alpha, GRO beta, and GRO gamma activate human neutrophil and basophil leukocytes. J Biol Chem 1993; 268: 15419-24.

[60] Prause O, Laan M, Lotvall J, Linden A. Pharmacological modulation of interleukin-17-induced GCP-2-, GRO-alpha- and interleukin-8 release in human bronchial epithelial cells. Eur J Pharmacol 2003; 462: 193-8.

[61] Li Z, Alam S, Wang J, Sandstrom CS, Janciauskiene S, Mahadeva R. Oxidized \{alpha\}1-antitrypsin stimulates the release of mono- 
cyte chemotactic protein-1 from lung epithelial cells: potential role in emphysema. Am J Physiol Lung Cell Mol Physiol 2009; 297: L388-400.

[62] Traves SL, Culpitt SV, Russell RE, Barnes PJ, Donnelly LE. Increased levels of the chemokines GROalpha and MCP-1 in sputum samples from patients with COPD. Thorax 2002; 57: 590-5.

[63] Cai S, Chen P, Zhu Y. [Airway inflammation and macrophage inflammatory protein-1alpha, gelatinase B level in patients with COPD]. Zhonghua Jie He He Hu Xi Za Zhi 2001; 24: 429-32.

[64] Barczyk A, Pierzchala W, Sozanska E. [Levels of CC-chemokine (MCP-1 alpha, MIP-1 beta) in induced sputum of patients with chronic obstructive pulmonary disease and patients with chronic bronchitis]. Pneumonol Alergol Pol 2001; 69: 40-9.

[65] Jahnz-Rozyk K, Chcialowski A, Pirozynska E, Rogalewska A. [Expression of adhesion molecules LFA-1 (CD11a and ICAM-1 (CD54) on lymphocytes and chemokines IL-8 and MCP-1 concentrations in bronchoalveolar lavage of patients with asthma or chronic obstructive pulmonary disease]. Pol Merkur Lekarski 2000; 9: 649-52

[66] Bonecchi R, Bianchi G, Bordignon PP, D'Ambrosio D, Lang R, Borsatti A, et al. Differential expression of chemokine receptors and chemotactic responsiveness of type $1 \mathrm{~T}$ helper cells (Th1s) and Th2s. J Exp Med 1998; 187: 129-34.

[67] Capelli A, Di Stefano A, Gnemmi I, Balbo P, Cerutti CG, Balbi B, et al. Increased MCP-1 and MIP-1beta in bronchoalveolar lavage fluid of chronic bronchitics. Eur Respir J 1999; 14: 160-5.

[68] Di Stefano A, Capelli A, Lusuardi M, Caramori G, Balbo P, Ioli F, et al. Decreased T lymphocyte infiltration in bronchial biopsies of subjects with severe chronic obstructive pulmonary disease. Clin Exp Allergy 2001; 31: 893-902.

[69] Grumelli S, Corry DB, Song LZ, Song L, Green L, Huh J, et al. An immune basis for lung parenchymal destruction in chronic obstructive pulmonary disease and emphysema. PLoS Med 2004; 1: e8.

[70] Saetta M, Di Stefano A, Maestrelli P, Turato G, Ruggieri MP, Roggeri A, et al. Airway eosinophilia in chronic bronchitis during exacerbations. Am J Respir Crit Care Med 1994; 150: 1646-52.

[71] Keatings VM, Collins PD, Scott DM, Barnes PJ. Differences in interleukin- 8 and tumor necrosis factor-alpha in induced sputum from patients with chronic obstructive pulmonary disease or asthma. Am J Respir Crit Care Med 1996; 153: 530-4.
[72] Zhu J, Qiu YS, Majumdar S, Gamble E, Matin D, Turato G, et al. Exacerbations of Bronchitis: bronchial eosinophilia and gene expression for interleukin-4, interleukin-5, and eosinophil chemoattractants. Am J Respir Crit Care Med 2001; 164: 109-16.

[73] Panina-Bordignon P, Papi A, Mariani M, Di Lucia P, Casoni G, Bellettato C, et al. The C-C chemokine receptors CCR4 and CCR8 identify airway $\mathrm{T}$ cells of allergen-challenged atopic asthmatics. J Clin Invest 2001; 107: 1357-64.

[74] Costa C, Rufino R, Traves SL, Lapa ESJR, Barnes PJ, Donnelly LE. CXCR3 and CCR5 chemokines in induced sputum from patients with COPD. Chest 2008; 133: 26-33.

[75] Smyth LJ, Starkey C, Gordon FS, Vestbo J, Singh D. CD8 chemokine receptors in chronic obstructive pulmonary disease. Clin Exp Immunol 2008; 154: 56-63.

[76] Miller M, Ramsdell J, Friedman PJ, Cho JY, Renvall M, Broide DH. Computed tomographic scan-diagnosed chronic obstructive pulmonary disease-emphysema: eotaxin-1 is associated with bronchodilator response and extent of emphysema. J Allergy Clin Immunol 2007; 120: 1118-25.

[77] Nocker RE, Schoonbrood DF, van de Graaf EA, Hack CE, Lutter $\mathrm{R}$, Jansen HM, et al. Interleukin-8 in airway inflammation in patients with asthma and chronic obstructive pulmonary disease. Int Arch Allergy Immunol 1996; 109: 183-91.

[78] Wang S, Xu F, Chen Y. [Detection and significance of interleukin8,6 , tumor necrosis factor-alpha in sputa from patients with chronic obstructive pulmonary disease]. Zhonghua Jie $\mathrm{He} \mathrm{He} \mathrm{Hu}$ Xi Za Zhi 2000; $23: 465-7$

[79] Schulz C, Wolf K, Harth M, Kratzel K, Kunz-Schughart L, Pfeifer M. Expression and release of interleukin- 8 by human bronchial epithelial cells from patients with chronic obstructive pulmonary disease, smokers, and never-smokers. Respiration 2003; 70: 25461 .

[80] Demedts IK, Bracke KR, Van Pottelberge G, Testelmans D, Verleden GM, Vermassen FE, et al. Accumulation of dendritic cells and increased CCL20 levels in the airways of patients with chronic obstructive pulmonary disease. Am J Respir Crit Care Med 2007; 175: 998-1005.

Received: December 20, 2009

Revised: March 15, 2010

Accepted: March 18, 2010

(C) Chen et al.; Licensee Bentham Open.

This is an open access article licensed under the terms of the Creative Commons Attribution Non-Commercial License (http://creativecommons.org/licenses/by-nc/3.0/) which permits unrestricted, non-commercial use, distribution and reproduction in any medium, provided the work is properly cited. 